\title{
Influence of Pilates training on muscular strength and flexibility in dancers
}

\author{
Tânia Patrícia Amorim ${ }^{1}$ \\ Filipa Manuel Sousa ${ }^{2}$ \\ José Augusto Rodrigues dos Santos ${ }^{1}$ \\ ${ }^{1}$ Track and Field Department, Faculty of Sports, University of Porto, Portugal \\ ${ }^{2}$ Biomechanics Laboratory, Faculty of Sports, University of Porto, Portugal
}

\begin{abstract}
The purpose of the present study was to assess the effects of a Pilates training program on muscular strength and flexibility in dance students. Fifteen dance students were divided into 2 groups: experimental $(n=7)$ and control $(n=8)$. Both were assessed in beginning and in the end of the study. Muscular strength was assessed measuring the time supported in the technical skills penché and developpé. To asses flexibility, it was measured the angle between limbs in the technical skills arabesque, developpé and cambré. After the first moment of evaluation, the experimental group performed a Mat-Based Pilates Exercise during 11 weeks. The statistic analyses (two-way analysis of variance - ANOVA 2x2) showed significant differences $(p \leq 0,05)$ in muscular strength and flexibility measurements between groups after the training program. It was concluded that Pilates training has a positive effect on muscular strength and flexibility in dance students.
\end{abstract}

Keywords: Dancers. Pilates. Muscular strength. Flexibility.

\section{Influência de um programa de treino Pilates na força muscular e flexibilidade de bailarinos}

Resumo: Foi objectivo avaliar o efeito de um programa de treino Pilates na força muscular e flexibilidade de bailarinos estudantes. Quinze bailarinos foram divididos em 2 grupos: experimental $(n=7)$ e controlo $(n=8)$. Ambos foram avaliados no início e final do estudo. A força muscular foi avaliada através do tempo de sustentação nos elementos técnicos penché e developpé. Para avaliar a flexibilidade foi medido o ângulo de amplitude entre os segmentos nos elementos técnicos arabesque, cambré e developpé. Após o 1.ำ momento de avaliação os bailarinos do grupo experimental participaram num programa de Mat-Based Pilates Exercise durante 11 semanas. A análise estatística (análise de variância para medidas repetidas ANOVA 2x2) demonstrou diferenças significativas $(p \leq 0,05)$ entre os grupos no âmbito da força muscular e flexibilidade após o programa de treino. Conclui-se que o Pilates induz alterações positivas ao nível da força muscular e flexibilidade de bailarinos.

Palavras-Chave: Bailarinos. Pilates. Força muscular. Flexibilidade.

\section{Introduction}

Dance is an art form and a mean of expression. However, a full development of several physical capacities are also needed, which turn dance into an artistic and athletic activity (KOUTEDAKIS; JAMURTAS, 2004). To achieve remarkable performances, it is required an expertise in the aesthetic and athletic side of the art, since the beauty of the technical skills presupposes a fully developed body (WELSH, 2009). Each movement has to be performed correctly, slowly, with control, without apparently effort (WELSH, 2009), being also necessary extreme range of motion at the ankle and hip joints (DEIGHAN, 2005). Therefore, a highly development of muscular strength and flexibility are physical demands placed on dancers.

Since physical conditioning is essential to dancer's performance, dance research have examined the effects of supplemental training to traditional dance classes. Published data have been proving that a complementary strength and flexibility training program has positive effects on technical PERFORMANCE (STALDER; NOBLE; WILKISON, 1990; GROSSMAN; WILMERDING, 2000; KOUTEDAKIS; SHARP, 2004; KOUTEDAKIS; HUKAM; METSIOS; NEVILL; GIAKAS; JAMURTAS; MYSZKEWYCZ, 2007). However, Koutedakis and Jamurtas (2004) highlight that "any change in the traditional training regimens must be approached cautiously to 
ensure that the aesthetic content of the dance is not affected by new training techniques". Therefore, it is important to understand the demands of dance to adapt the complementary training according to dance characteristics and principles, meeting the exact needs of dance technique.

From this point, we would like to highlight the Pilates method, that despite the frequent use, it has not been sufficiently investigated in relation to dance performance (BERNARDO; NAGLE, 2006). This technique is point out in the literature has beneficial to improve the general muscular strength and flexibility (SEKENDIZ; ALTUN; KORKUSUZ; AKIN, 2007; ROGERS; GIBSON, 2009; KLOUBEC, 2010), which are capacities essentials to dancers. Besides, the Pilates method has inherent principles such as control, concentration, centering, flow of movement, precision and breathing, involving likewise planes of movement similar to dance technique (AHEARN, 2006). Hence, as it is possible to recognize movement patterns and principles in Pilates method that converge with dance technique, and since it has been suggested that the ideally complementary training should fulfill with dance technique demands, the vital issue that arises is: Can Pilates technique be useful to improve dancers' performance, being a promise tool to be used as complementary strength and flexibility training?

The purpose of the present study was to test the effectiveness of a Pilates training program to develop muscular strength and flexibility in dance students.

\section{Subjects}

\section{Methods}

Fifteen dance students, 12 women and 3 men, with more than ten years of daily practice in dance voluntarily in the study. Dancers were from the same institution (Ginasiano Dancing School), and none of them present, until the moment, any kind of injury that could influence their performances. Subjects were assigned into experimental (EG) and control (CG) groups. The EG was composed by 7 dancers ( 6 women and 1 men; age: 15,7 \pm 0,8 years old; experience of dance training: $11 \pm$ 2,7 years), and the CG by 8 dancers ( 6 women and 2 men; age: 16,3 $\pm 0,9$ years old; experience of dance training: 11,9 $\pm 3,7$ years). All the groups participated in the classes of their scholar curricula. The EG attended 6 hours a week of classical and modern dance technique, 1 hour and half of pas de deux and 1 hour of character dance. The CG attended 7 hours a week of classical and modern dance technique, 1 hour and half of pas de deux and 1 hour of character dance.

All subjects signed a written agreement in compliance with the University of Porto ethical committee.

\section{Training Protocol}

This is an experimental study with two moments of evaluation. After the first moment of evaluation (measurement of initial muscular strength and flexibility levels), only the EG performed a Mat-Based Pilates Exercises during 11 weeks (2 sessions per week of 60 minutes). After the Pilates sessions, both groups were submitted at a second moment of evaluation with the same features as the first one. During the research both groups attended the usual dance classes.

The Pilates training protocol was supervisor by a qualified Pilates instructor. Basic and intermediate exercises were employed; advanced exercises were added as technique and time of training progressed. At the beginning of the training protocol, all dancers performed, slowly, 3 sets of 8 repetitions of each exercise; increasing 1 repetition each week till 12 repetitions were reached. After reaching the 12 repetitions it was introduced the intermediate or advanced form of each exercise, performing 3 sets of 8 repetitions. In the sessions it was used exercises with a similarity with dance technique (e.g. "scissors", "the hundred", "side bend", "side kick", "back support"). Each session was set up in 3 phases: warm-up (15 minutes), Pilates exercises (35 minutes) and cool-down (10minutes).

\section{Muscular strength measurement}

It was evaluated the isometric strength of the lower limbs. Subjects were asked to maintain as long as possible, with both limbs, the technical skills penché and developpé (front, side, back) in the barre. It was timed how long each dancer could sustain the positions, without swinging the body. This protocol is used by the Federation Internationale de Gymnastique (Physical Testing Program), and its choice derives from the functional similarity with dance exercises. The evaluation tests were preceded by a period of warming. 


\section{Flexibility measurement}

Three technical skills were assessed, collected on the right and left side: arabesque, cambré backward (in the barre) and developpé (front, side, back), also in the barre. Two high definition cameras, Casio Digital Camera EX-F1 were used to photograph the chosen movements. It was used a calibration scale placed next to a moving barre (Figure 1). The two cameras were directed to the calibration scale, one in the front, and other in the rear of the scale. During data collection, the positions of the cameras and calibration scale were not modified; it was only modified the position of the barre to assess the technical skills developpé front and cambré.

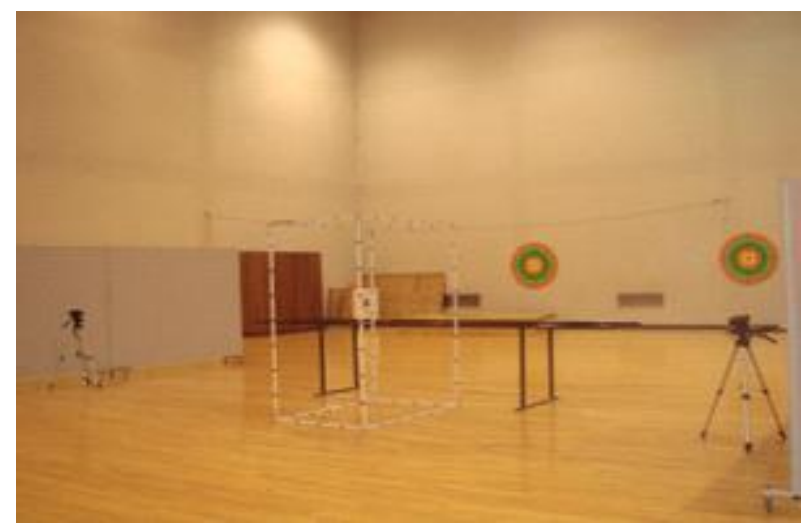

Figure 1. Assembling material for data collection

Each dancer was marked in the following anatomical points: ankle joint, knee joint, iliac crest, shoulder joint, elbow joint and wrist joint. After, each dancer performed the different technical skills inside the calibration scale; both cameras captured the images (10 frames per second at 3 megapixel resolution).

After data collection, it was selected only one photo for each skill, taking as selection criterion the most corrected technical execution and the highest point for limbs extension.

The angles among body segments were assessed through Matlab routines (Figure 2). For the technical skills arabesque, developpé back and developpé side, points were marked in the inner sides of ankle and knee joints of both limbs. For the developpé front the points were marked in the inner side of ankle and knee joints (supporting limb) and in the external side of ankle and knee joints (elevating limb). For assessing the angle between the trunk and the lower limbs in the technical element cambré, points were marked in the knee joint, iliac crest, shoulder joint and elbow joint.

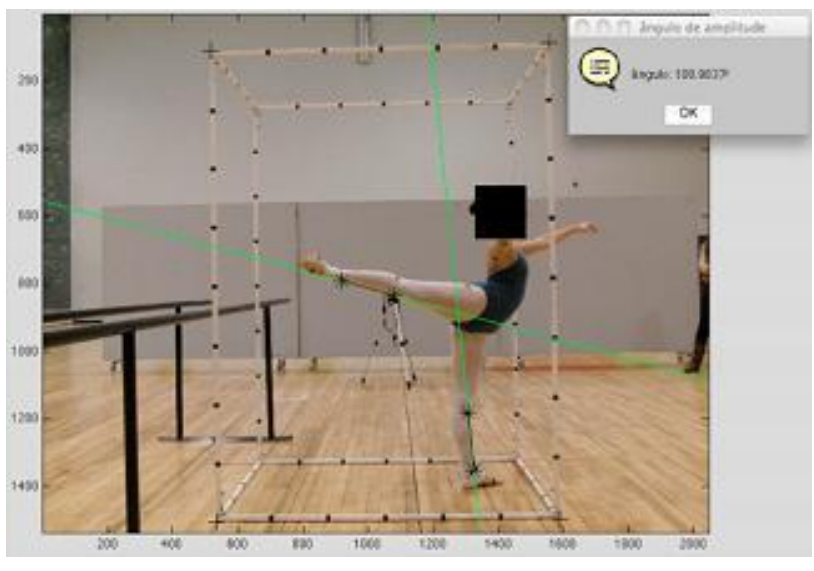

Figure 2. Example in how angle between body segments were obtained; asterisks represent the anatomical points marked for obtain the angle between body segments in this technical skill (arabesque). For each technical skill were marked different anatomical points.

\section{Statistical Analyses}

Mean ( \pm sd) was calculated for all parameters.

Data from experimental and control groups were normally distributed. Comparisons between the first and second moment of evaluation and between experimental and control groups were made using two-way analysis of variance ANOVA $2 \times 2$ (group $X$ moment), with moment being a repeated factor.

All statistical analysis were performed using SPSS (Statistical Package for the Social Sciences, 19.0), and the criterion for significance was set at $p \leq 0,05$.

\section{Results}

Significant results can be analyzed in table 1 and 2 .

Table 1 presents results for muscular strength pre and post-Pilates training in EG and $C G$. EG and $C G$ had similar pre-Pilates muscular strength range in all technical skills evaluated. However, after Pilates training, EG increased their range in all technical skills. This increasing were not followed by $C G$, being stated a significant group $x$ moment interaction $(p \leq 0,05)$ in all technical skills evaluated. This significant interaction revealed that muscular strength was significantly higher in the $E G$ after Pilates training. 
Table 1. Muscular strength measures (seconds) pre and post-Pilates training.

\begin{tabular}{|c|c|c|c|c|c|c|c|}
\hline & \multicolumn{2}{|c|}{ Experimental group } & \multicolumn{2}{|c|}{ Control group } & \multirow[b]{2}{*}{ Effects } & \multirow[b]{2}{*}{$\mathbf{F}$} & \multirow[b]{2}{*}{$p$} \\
\hline & $\begin{array}{c}\text { Pre-Pilates } \\
x \pm s d\end{array}$ & $\begin{array}{c}\text { Pos-Pilates } \\
\mathrm{x} \pm \text { sd }\end{array}$ & $\begin{array}{c}\text { Pre-Pilates } \\
x \pm \text { sd }\end{array}$ & $\begin{array}{c}\text { Pos-Pilates } \\
x \pm s d\end{array}$ & & & \\
\hline $\begin{array}{l}\text { Penché } \\
\text { Right limb }\end{array}$ & $25,1 \pm 11,3$ & $47,6 \pm 22,3$ & $24,9 \pm 4,3$ & $26,8 \pm 3,2$ & $\begin{array}{c}\text { Group } \\
\text { Moment } \\
\text { Group X Moment }\end{array}$ & $\begin{array}{c}3,324 \\
20,764 \\
14,851\end{array}$ & $\begin{array}{l}0,091 \\
0,001 \\
0,002\end{array}$ \\
\hline $\begin{array}{l}\text { Penché } \\
\text { Left limb }\end{array}$ & $35,1 \pm 13,4$ & $49,4 \pm 17,81$ & $24,5 \pm 8,1$ & $24,4 \pm 7,7$ & $\begin{array}{c}\text { Group } \\
\text { Moment } \\
\text { Group X Moment }\end{array}$ & $\begin{array}{c}8,806 \\
14,264 \\
14,772 \\
\end{array}$ & $\begin{array}{l}0,000 \\
0,002 \\
0,002\end{array}$ \\
\hline $\begin{array}{l}\text { Developpé front } \\
\text { Right limb }\end{array}$ & $12,9 \pm 5,1$ & $19,9 \pm 6,2$ & $14,8 \pm 4,1$ & $14,3 \pm 4,2$ & $\begin{array}{c}\text { Group } \\
\text { Moment } \\
\text { Group X Moment }\end{array}$ & $\begin{array}{c}0,678 \\
8,073 \\
10,748\end{array}$ & $\begin{array}{l}0,425 \\
0,014 \\
0,006\end{array}$ \\
\hline $\begin{array}{l}\text { Developpé front } \\
\text { Left limb }\end{array}$ & $17,7 \pm 7,1$ & $23,9 \pm 8,2$ & $12,3 \pm 2,7$ & $12,4 \pm 3,1$ & $\begin{array}{c}\text { Group } \\
\text { Moment } \\
\text { Group X Moment }\end{array}$ & $\begin{array}{c}8,891 \\
21,733 \\
20,034 \\
\end{array}$ & $\begin{array}{l}0,000 \\
0,000 \\
0,001\end{array}$ \\
\hline $\begin{array}{l}\text { Developpé side } \\
\text { Right limb }\end{array}$ & $15,0 \pm 4,0$ & $22,9 \pm 11$ & $14,0 \pm 4,2$ & $14,1 \pm 4,6$ & $\begin{array}{c}\text { Group } \\
\text { Moment } \\
\text { Group X Moment }\end{array}$ & $\begin{array}{c}2,571 \\
10,456 \\
9,812\end{array}$ & $\begin{array}{l}0,133 \\
0,007 \\
0,008\end{array}$ \\
\hline $\begin{array}{l}\text { Developpé side } \\
\text { Left limb }\end{array}$ & $16,6 \pm 8,9$ & $24,7 \pm 6,5$ & $12,5 \pm 2,9$ & $12,8 \pm 2,4$ & $\begin{array}{c}\text { Group } \\
\text { Moment } \\
\text { Group X Moment }\end{array}$ & $\begin{array}{c}8,359 \\
20,306 \\
17,959 \\
\end{array}$ & $\begin{array}{l}0,013 \\
0,001 \\
0,001\end{array}$ \\
\hline $\begin{array}{l}\text { Developpé back } \\
\text { Right limb }\end{array}$ & $29,3 \pm 11,9$ & $49,0 \pm 14,9$ & $24,9 \pm 7,4$ & $25,0 \pm 6,0$ & $\begin{array}{c}\text { Group } \\
\text { Moment } \\
\text { Group X Moment }\end{array}$ & $\begin{array}{c}8,929 \\
18,465 \\
16,266\end{array}$ & $\begin{array}{l}0,010 \\
0,001 \\
0,001\end{array}$ \\
\hline $\begin{array}{l}\text { Developpé back } \\
\text { Left limb }\end{array}$ & $40,9 \pm 9,2$ & $52,7 \pm 12,6$ & $26,9 \pm 4,8$ & $26,9 \pm 5,7$ & $\begin{array}{c}\text { Group } \\
\text { Moment } \\
\text { Group X Moment }\end{array}$ & $\begin{array}{c}26,638 \\
8,415 \\
8,415 \\
\end{array}$ & $\begin{array}{l}0,000 \\
0,012 \\
0,012\end{array}$ \\
\hline
\end{tabular}

Table 2. Flexibility measures (degrees) pre and post-Pilates training.

\begin{tabular}{|c|c|c|c|c|c|c|c|}
\hline & \multicolumn{2}{|c|}{ Experimental group } & \multicolumn{2}{|c|}{ Control group } & \multirow[b]{2}{*}{ Effects } & \multirow[b]{2}{*}{$\mathbf{F}$} & \multirow[b]{2}{*}{$p$} \\
\hline & $\begin{array}{c}\text { Pre-Pilates } \\
x \pm \text { sd }\end{array}$ & $\begin{array}{c}\text { Pos-Pilates } \\
x \pm \text { sd }\end{array}$ & $\begin{array}{l}\text { Pre-Pilates } \\
x \pm \text { sd }\end{array}$ & $\begin{array}{c}\text { Pos-Pilates } \\
x \pm \text { sd }\end{array}$ & & & \\
\hline $\begin{array}{l}\text { Arabesque } \\
\text { Right limb }\end{array}$ & $99,3 \pm 8,9$ & $109,2 \pm 12,7$ & $96,4 \pm 4,2$ & $97,0 \pm 4,7$ & $\begin{array}{c}\text { Group } \\
\text { Moment } \\
\text { Group X Moment }\end{array}$ & $\begin{array}{c}3,467 \\
19,349 \\
15,158\end{array}$ & $\begin{array}{l}0,085 \\
0,001 \\
0,002\end{array}$ \\
\hline $\begin{array}{l}\text { Arabesque } \\
\text { Left limb }\end{array}$ & $102,2 \pm 12,1$ & $109,5 \pm 11,0$ & $93,4 \pm 6,5$ & $95,0 \pm 4,5$ & $\begin{array}{c}\text { Group } \\
\text { Moment } \\
\text { Group X Moment }\end{array}$ & $\begin{array}{l}6,946 \\
8,485 \\
3,451 \\
\end{array}$ & $\begin{array}{l}0,021 \\
0,012 \\
0,086\end{array}$ \\
\hline $\begin{array}{l}\text { Developpé front } \\
\text { Right limb }\end{array}$ & $102,3 \pm 12,7$ & $112,0 \pm 13,1$ & $102,4 \pm 10,2$ & $101,5 \pm 8,7$ & $\begin{array}{c}\text { Group } \\
\text { Moment } \\
\text { Group X Moment }\end{array}$ & $\begin{array}{c}0,886 \\
7,413 \\
10,457\end{array}$ & $\begin{array}{l}0,364 \\
0,017 \\
0,007\end{array}$ \\
\hline $\begin{array}{l}\text { Developpé front } \\
\text { Left limb }\end{array}$ & $102,2 \pm 13,5$ & $110,3 \pm 13,3$ & $95,5 \pm 5,3$ & $96,2 \pm 5,7$ & $\begin{array}{c}\text { Group } \\
\text { Moment } \\
\text { Group X Moment }\end{array}$ & $\begin{array}{c}4,161 \\
22,870 \\
16,012 \\
\end{array}$ & $\begin{array}{l}0,062 \\
0,000 \\
0,002\end{array}$ \\
\hline $\begin{array}{l}\text { Developpé side } \\
\text { Right limb }\end{array}$ & $115,7 \pm 21,9$ & $125,7 \pm 18,7$ & $110,1 \pm 13,4$ & $110,7 \pm 12,5$ & $\begin{array}{c}\text { Group } \\
\text { Moment } \\
\text { Group X Moment }\end{array}$ & $\begin{array}{c}1,450 \\
19,449 \\
15,063\end{array}$ & $\begin{array}{l}0,250 \\
0,001 \\
0,002\end{array}$ \\
\hline $\begin{array}{l}\text { Developpé side } \\
\text { Left limb }\end{array}$ & $113,9 \pm 88,1$ & $121,5 \pm 18,0$ & $108,8 \pm 14,4$ & $109,7 \pm 12,9$ & $\begin{array}{c}\text { Group } \\
\text { Moment } \\
\text { Group X Moment }\end{array}$ & $\begin{array}{c}1,048 \\
30,312 \\
18,712 \\
\end{array}$ & $\begin{array}{l}0,325 \\
0,000 \\
0,001\end{array}$ \\
\hline $\begin{array}{l}\text { Developpé back } \\
\text { Right limb }\end{array}$ & $112,2 \pm 10,1$ & $119,8 \pm 12,9$ & $103,8 \pm 6,9$ & $102,2 \pm 5,8$ & $\begin{array}{c}\text { Group } \\
\text { Moment } \\
\text { Group X Moment }\end{array}$ & $\begin{array}{l}8,231 \\
3,708 \\
8,809\end{array}$ & $\begin{array}{l}0,013 \\
0,076 \\
0,011\end{array}$ \\
\hline $\begin{array}{l}\text { Developpé back } \\
\text { Left limb }\end{array}$ & $113,8 \pm 13,1$ & $117,3 \pm 12,9$ & $102,6 \pm 4,2$ & $102,2 \pm 4,4$ & $\begin{array}{c}\text { Group } \\
\text { Moment } \\
\text { Group X Moment }\end{array}$ & $\begin{array}{l}7,530 \\
4,450 \\
7,048\end{array}$ & $\begin{array}{l}0,017 \\
0,055 \\
0,020\end{array}$ \\
\hline $\begin{array}{l}\text { Cambré backward } \\
\text { Right limb }\end{array}$ & $91,9 \pm 24,1$ & $88,0 \pm 23,3$ & $88,1 \pm 14,0$ & $87,6 \pm 15,9$ & $\begin{array}{c}\text { Group } \\
\text { Moment } \\
\text { Group X Moment }\end{array}$ & $\begin{array}{l}0,046 \\
1,855 \\
1,023\end{array}$ & $\begin{array}{l}0,833 \\
0,196 \\
0,330\end{array}$ \\
\hline $\begin{array}{l}\text { Cambré backward } \\
\text { Left limb }\end{array}$ & $95,2 \pm 20,4$ & $88,9 \pm 20,4$ & $93,9 \pm 17,7$ & $92,4 \pm 15,8$ & $\begin{array}{c}\text { Group } \\
\text { Moment } \\
\text { Group X Moment }\end{array}$ & $\begin{array}{l}0,012 \\
5,220 \\
2,035\end{array}$ & $\begin{array}{l}0,913 \\
0,040 \\
0,177\end{array}$ \\
\hline
\end{tabular}


Table 2 presents results for flexibility pre and post-Pilates training in EG and CG. EG and CG were found to have similar flexibility range in all technical skills measured at the first moment of evaluation, but EG had significantly greater flexibility increases in the technical skills arabesque (right limb), developpé front, developpé side and developpé back after Pilates training. This meant that EG had better flexibility range at the final measurement, being stated a significant group $\mathrm{x}$ moment interaction $(p \leq 0,05)$ in these technical skills. However, analysis revealed that there were no significant main or interaction effect on the technical skill cambré backward and arabesque (left limb), being the group $\mathrm{x}$ moment interaction not significant $(p \geq 0,05)$. This meant that both groups did not improve significantly their flexibility range in these technical skills. However, despite not being significant, EG had increased their flexibility range in 7,3 degrees on the technical skill arabesque (left limb).

\section{Discussion}

The main aim of this study was to investigate the effects of Pilates training on muscular strength and flexibility in dancers, trying to test that this technique can be useful to dancers. For the purpose of this study, it was selected a range of technical skills that require the use of flexibility and muscular strength. Since dance skills are usual performed with each limb in separate, data were collected with both limbs, measured separately. However, it is not purpose of this study to establish comparisons between limbs.

From the analyses, the present results demonstrated that Pilates training increased dancers' muscular strength levels. Since there are not similar studies, it is not possible to compare directly these results. Studies realized with other populations corroborate our results. So, several authors have demonstrated that a Pilates training program had a positive impact on muscular strength levels in sedentary populations (SEKENDIZ; ALTUN; KORKUSUZ; AKIN, 2007; ROGERS; GIBSON, 2009; KLOUBEC, 2010).

Apparently, the nature of Pilates training can explain the strength gains found in the present study. Analyzing dancers training patterns, abdominal muscle development is neglected, what rises the importance for the training of this crucial musculature. Abdominal muscles in normal dance training is only stimulated by the characteristic attitude of dance, which emphasizes the pelvic retroversion position. Pilates training, continuously stimulating the abdominal musculature provides a stronger core, which is essential for set and support the kinetic chains required to raise lower limbs. Better improvements can be verified in the technical skills penché and developpé back. The constant gluteal muscles contraction required by Pilates exercises, is probably the main cause for the greatest improvements on muscular strength in these technical skills.

The present study showed significant increase on the flexibility assessed by the technical skills arabesque and developpé. No other studies with dancers were found, however several authors have noted positive impacts of Pilates training on the flexibility of sedentary subjects (SEKENDIZ; ALTUN; KORKUSUZ; AKIN, 2007; KLOUBEC, 2010) and soccer players (BERTOLLA; BARONI; JUNIOR; OLTRAMI, 2007). However, it is necessary to highlight that these studies used different methods and different body zones measurements. We want to reinforce the present data validity because the sample of the present study was composed by subjects who already had great levels of global flexibility. However, some assumptions should be considered. Albeit the literature suggest that static stretching improves flexibility better than dynamic stretching (BANDY; IRON, 1994; BANDY; IRION; BRIGGLER, 1997; ROBERTS; WILSON, 1999; HEDRICK, 2000), the present study showed significant flexibility gains through dynamic exercises. Furthermore, it can be speculate that flexibility gains noted in the present study could also be related to muscular strength gains after the Pilates training. The relationship between muscular strength and flexibility has been stated by several authors (LEIGHTON, 1964; FATAUROS; TAXILDARIS; TOKMADAKIS; KLAPOTHARAKOS; AGGELOUSIS; ATHANASOPOULOS; ZEERIS; KATRABAS, 2002; FATAUROS; KAMBAS; KATRABASSAS; LEONTSINI; CHATZINIKOLAOU; JAMURTAS; DOUROUDOS; AGGELOUSIS; TAXILDARIS, 2006; SANTOS; RHEA; SIMÃO; DIAS; SALLES; NOVAES; LEITE; BLAIR; BUNKER, 2010), however flexibility benefits obtained by strength training require maximum range of motion during strength exercises (STONE; FLECK; TRIPLETT; KRAMER, 1991). It should be pointed out the 
importance of muscular strength training in dancing, since dancers often show great levels of flexibility, but do not have strength enough to perform movements with maximum range of motion. Facing the impossibility of knowing exactly the contribution of muscle strength to flexibility gains noted in the present study, it can be only speculate that the execution of movements with full range of motion and with some static sustenance require high strength levels besides a great neuromotor coordination between agonist and antagonist muscles.

Pilates training did not improve flexibility in the technical skill cambré. Probably this is due to the weak stimulation of dorsal and lumbar muscles elicited by the Pilates exercises used. Therefore, the slight flexibility gains noticed in cambré, are probably due to the usual stimulus provided by dance classes.

As a conclusion, the present data confirmed that Pilates training can significant improve dancers' muscular strength and flexibility, affecting positively dance performance. As Pilates exercises emphasizes movements with some kinetic similarity to dance technique, we believe that this type of training is suitable for dancers to improve muscular strength and flexibility.

\section{Referências}

AHEARN, E. L. The Pilates method and ballet technique: applications in dance studio. Journal of Dance Education, Philadelphia, v. 6, n. 3, p. 92-99, 2006.

BANDY, W. D.; IRION, J. M. The effect of time on static stretch on the flexibility of the hamstring muscles. Physical Therapy, Alexandria, v. 74, n. 9, p. 54-60, 1994.

BANDY, W. D.; IRION, J. M.; BRIGGLER, M. The effect of time and frequency of static stretching on flexibility of the hamstring muscles. Physical Therapy, Alexandria, v. 77, n. 10, p. 1090-1096, 1997.

BERNARDO, L. M.; NAGLE, E. F. Does Pilates training benefit dancers?: an appraisal of pilates research literature. Journal of Dance Medicine \& Science, Eugene, v. 10, n. 1/2, p. 46-50, 2006.

BERTOLLA, F.; BARONI, B. M.; JUNIOR, E. C.; OLTRAMI, J. D. Effects of a training program using the Pilates method in flexibility of sub- 20 indoor soccer athletes. Revista Brasileira de Medicina do Esporte, Niterói, v. 4, p. 198-202, 2007.

DEIGHAN, M. Flexibility in dance. Journal of Dance Medicine \& Science, Eugene, v. 9, n. 1, p. 13-17, 2005.

FATOUROS, I.; KAMBAS, A.; KATRABASSAS, I.; LEONTSINI, D.; CHATZINIKOLAOU, A.; JAMURTAS, A.; DOUROUDOS, I.; AGGELOUSIS, N.; TAXILDARIS, K. Resistance training and detraining effects on flexibility peformance in the elderly are intensity-dependent. Journal of Strength and Conditioning Research, Philadelphia, v. 20, n. 3, p. 634-642, 2006.

FATAUROS, I. G.; TAXILDARIS, K.; TOKMADAKIS, S. P.; KLAPOTHARAKOS, V.; AGGELOUSIS, N.; ATHANASOPOULOS, S.; ZEERIS, I.; KATRABAS, I. The effects of strength training, cardiovascular training and their combination on flexibility of inactive older adults. International Journal of Sports Medicine, Stuttgart, v. 23, p. 112-119, 2002.

GROSSMAN, G.; WILMERDING, M. The effect of conditioning on the height of dancer's extension in à la seconde. Journal of Dance Medicine \& Science, Eugene, v. 4, n. 4, p. 117-21, 2000.

HEDRICK, A. Dynamic flexibility training. Strength and Conditioning Journal, Philadelphia, v. 22, n. 5, p. 33-38, 2000.

KLOUBEC, J. A. Pilates for improvement of muscle endurance, flexibility, balance and posture. Journal of Strength and Conditioning Research, Philadelphia, v. 24, n. 3, p. 661-667, 2010.

KOUTEDAKIS, Y.; JAMURTAS, A. The dancer as a performing athlete: physiological considerations. Sports Medicine, Auckland, v. 34, n. 10, p. 651$661,2004$.

KOUTEDAKIS, Y.; SHARP, N. Thigh-muscles strength training, dance exercise, dynamometry, and anthropometry in professional ballerinas. Journal of Strength and Conditioning Research, Philadelphia, v. 18, n. 4, p. 714-718, 2004.

KOUTEDAKIS, Y.; HUKAM, H.; METSIOS, G.; NEVILL, A.; GIAKAS, G.; JAMURTAS, A.; MYSZKEWYCZ, L. The effects of three months of 
aerobic and strength training on selected performance-and fitness-related parameters in modern dance students. Journal of Strength and Conditioning Research, Philadelphia, v. 3, n. 21, p. 808-812, 2007.

LEIGHTON, J. R. A study of the effect of progressive weight training on flexibility. Journal of Association for Physical and Mental Rehabilitation, Hattiesburg, v. 18, p. 101-104, 1964.

ROBERTS, J. M.; WILSON, K. Effect of stretching duration on active and passive range of motion in the lower extremity. British Journal of Sports Medicine, London, v. 33, p. 259-263, 1999.

ROGERS, K.; GIBSON, A. L. Eigth-week traditional mat pilates training-program effects on adult fitness characteristics. Research Quarterly for Exercise and Sport, Reston, v. 80, n. 3, p. 569-574, 2009.

SANTOS, E.; RHEA, M. R.; SIMÃO, R.; DIAS, I.; SALLES, B. F.; NOVAES, J.; LEITE, T.; BLAIR, J. C.; BUNKER, D. J. Influence of moderately intense strength training on flexibility in sedentary young women. Journal of Strength and Conditioning Research, Philadelphia, v. 24, n. 11, p. 3144-3149, 2010.

SEKENDIZ, B.; ALTUN, O.; KORKUSUZ, F.; AKIN, S. Effects of Pilates exercise on trunk strength, endurance and flexibility in sedentary adult females. Journal of Bodywork and Movement Therapies, Kidlington, v. 11, p. 318326, 2007.

STALDER, M. A.; NOBLE, B. J.; WILKISON, J. G. The effects of supplemental weight training for ballet dancers. Journal of Applied Sport Science Research, Philadelphia, v. 4, n. 3, p. 95$102,1990$.

STONE, M. H.; FLECK, S. J.; TRIPLETT, N. T.; KRAMER, W. J. Health and performance related potential of resistance training of resistance training. Sports Medicine, Auckland, v. 11, p. 210-231, 1991.

WELSH, T. Conditioning for dancers. Florida: University Press of Florida, 2009.

\author{
Endereço: \\ Tânia Patrícia Amorim \\ Rua Dr. Plácido Costa, 91 \\ Track and Field Department; 4200-45 \\ Porto Portugal \\ e-mail: tania_amorim@hotmail.com
}

Recebido em: 9 de março de 2011.

Aceito em: 23 de agosto de 2011.

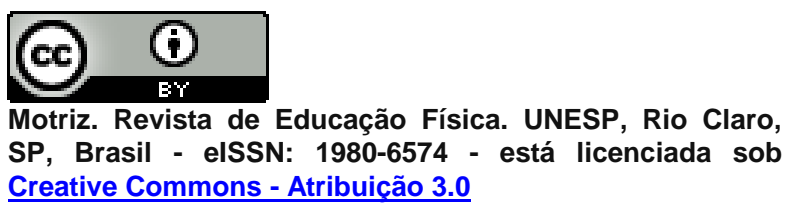

